\title{
ДИДАКТИЧНІ ОСОБЛИВОСТІ ВИКЛАДАННЯ ПСИХОЛОГІЧНИХ ДИСЦИПЛІН ПІД ЧАС ПІДГОТОВКИ ОФІЦЕРСЬКИХ КАДРІВ
}

\author{
Криворучко І. Я. \\ кандидат педагогічних наук, \\ старший викладач кафедри психології, педагогіки та сочіально-економічних дисциплін \\ Наџіональна академія Державної прикордонної служби України імені Богдана Хмельницького \\ вул. Шевченка, 46, Хмельницький, Україна \\ orcid.org/0000-0002-0149-8512 \\ krivir25@ukr.net
}

\begin{abstract}
Ключові слова: майбутні офіиери-прикордонники, психологічна підготовка, професійна діяльність, прикордонне відомство, освітній проиес.
\end{abstract}

Стаття присвячена сучасним проблемам вищої військової освіти в Україні. У контексті проблематики виокремлено питання психологічної підготовки фахівців непсихологічних спеціалізацій Державної прикордонної служби України. Проаналізовано зміст психологічної підготовки загалом у вищій освіті, а також у прикордонному відомстві. Метою статті є аналіз дидактичних особливостей викладання психологічних навчальних дисциплін майбутнім офіцерам-прикордонникам. Наведено мету та завдання психологічної підготовки у вищому військовому навчальному закладі прикордонної служби. Для детального аналізу дидактичних особливостей викладання психологічних навчальних дисциплін взято дисципліну «Морально-психологічне забезпечення». Визначено основну специфіку цієї дисципліни на основі аналізу змісту професійної діяльності офіцерів прикордонних підрозділів. Виокремлено основні дидактичні особливості викладання зазначеної вище навчальної дисципліни: доступне викладання (психологія використовує досить складну термінологію, а для майбутніх офіцерів-прикордонників психологічну освіту можна вважати початковою); відсутність систематичної психологічної підготовки майбутніх офіцерів-прикордонників вимагає від науково-педагогічних працівників здійснювати ретельну побудову тематичного плану (послідовну, логічну, раціональну) та добір педагогічних технологій, методик, методів, прийомів та засобів; формування основ критичного аналізу наукових положень; визначення рівня знайомства курсантівприкордонників із досягненнями поп-психології (популярної психології, що формує хибні явлення про наукову психологію) та спрямування зусиль на заміщення хибних знань та умінь на професійні; виділення вагомої частки аудиторних годин на практичну підготовку (оволодіння навичками проведення психологічних досліджень у прикордонному колективі та обробки їх результатів); дотримання принципу міждисциплінарності (зв'язку навчальної дисципліни 3 гуманітарними, природничими та військово-професійними дисциплінами); забезпечення чуттєвого наповнення змісту психологічної підготовки (здатність до міркувань про психіку інших людей); дотримання принципу цінності наукових професійних умінь порівняно зі знаннями. Сформульовано висновки за результатами проведеної дослідної роботи (доведено необхідність психологічної підготовки та дидактичні особливості викладання психологічних наук) та перспективи подальших наукових досліджень (присвячених вивченню зарубіжного досвіду та пропозицій щодо удосконалення змісту психологічної підготовки військових фахівців). 


\title{
DIDACTIC FEATURES OF TEACHING PSYCHOLOGICAL DISCIPLINES DURING THE TRAINING OF MILITARY PERSONNEL
}

\author{
Krivoruchko I. Ya. \\ Ph. D. in Pedagogy, \\ Senior Lecturer at the Department of Psychology, Pedagogy and Socio-Economic Disciplines \\ National Academy of the State Border Guard Service of Ukraine named after Bohdan Khmelnytskyi \\ Shevchenka str., 46, Khmelnytskyi, Ukraine \\ orcid.org/0000-0002-0149-8512 \\ krivir25@ukr.net
}

Key words: future border officers, psychological training, professional activity, border department, educational process.

\begin{abstract}
The article is devoted to modern problems of higher military education in Ukraine. In the context of the issue, the issue of psychological training of specialists in non-psychological specializations of the State Border Guard Service of Ukraine is singled out. The content of psychological training in general in higher education, as well as in the border department is analysed. The purpose of the article is to analyse the didactic features of teaching psychological disciplines to future border guards. The purpose and tasks of psychological training in the higher military educational institution of the border service are presented. For a detailed analysis of the didactic features of teaching psychological disciplines, the discipline "Moral and psychological support" was taken. The main specifics of this discipline are determined on the basis of the analysis of the content of professional activity of officers of frontier divisions. The main didactic features of teaching the above discipline are highlighted: accessible teaching (psychology uses quite complex terminology, and for future border guards, psychological education can be considered primary); the lack of systematic psychological training of future border guards requires research and teaching staff to carefully build a thematic plan (consistent, logical, rational) and selection of pedagogical technologies, methods, techniques, techniques and tools; formation of bases of the critical analysis of scientific positions; determining the level of acquaintance of border cadets with the achievements of pop psychology (popular psychology, which forms erroneous phenomena of scientific psychology) and directing efforts to replace erroneous knowledge and skills with professional ones; allocation of a significant share of classroom hours for practical training (mastering the skills of psychological research in the border team and processing their results); adherence to the principle of interdisciplinary (connection of academic discipline with humanities, natural sciences and military-professional disciplines); providing sensory content of psychological training (the ability to reason about the psyche of others); adherence to the principle of the value of scientific professional skills over knowledge. The conclusions of the research work (the need for psychological training and didactic features of teaching psychological sciences) and prospects for further research (devoted to the study of foreign experience and proposals to improve the content of psychological training of military professionals) are formulated.
\end{abstract}

Постановка проблеми. Соціальні інститути українського суспільства потребують реалізації процесів оновлення, перетворення, іноді докорінних змін, щоб забезпечити високий рівень його розвитку. Не $\epsilon$ винятком і соціальне утворення під назвою «прикордонна служба України», що виконує роль правоохоронного органу спеціального призначення. Загальноприйняте твердження щодо безперервного розвитку суспільства означає, що його фундаментальні інститути (до яких також належить прикордонне відомство) постійно розвиваються. 3-поміж безлічі ознак, що свідчать про реформування сучасної прикордонної служби, можна виокремити внесення психологічної підготовки у зміст професійної підготовки майбутніх офіцерів-прикордонників. Вищий навчальний заклад (далі - ВВНЗ) Державної прикордонної служби України (далі - ДПСУ), яким є Національна академія Державної прикордонної служби України імені Богдана Хмельницького 
(далі - НАДПСУ), здійснює підготовку офіцерських кадрів для зазначеного відомства, а отже, для всіх спеціальностей («Безпека державного кордону», «Філологія», «Автомобільний транспорт», «Телекомунікація», «Правоохоронна діяльність», «Психологія»).

Проблемі психологічної підготовки офіцерських кадрів присвячено чимало наукових праць: публікацій, монографій, дисертацій тощо. Заслуговують на увагу праці як вітчизняних, так і зарубіжних учених. Зокрема, загальні проблеми вищої освіти в України висвітлені у працях Л. Атанова [1], Е. Бондарчука [2], С. Матюхи [6], Л. Подоляка [7], О. Пометун [8], В. Семиченка [9]. Проблеми підвищення рівня професіоналізму офіцерів-прикордонників висвітлені у дослідженнях Л. Боровик [3], О. Войцехівського [4], Т. Івашкової [5], В. Мороз [10], О. Торічного [11] та багатьох інших.

Метою статті $\epsilon$ аналіз дидактичних особливостей викладання психологічних навчальних дисциплін для нефахових психологів - майбутніх офіцерів-прикордонників.

Виклад основного матеріалу дослідження. Задля висвітлення дидактичних особливостей викладання психологічних навчальних дисциплін для нефахових психологів необхідно проаналізувати специфіку професійної діяльності офіцерів ДПСУ.

Загальноприйнятим в Україні $є$ сприйняття офіцерів-прикордонників як виконавців паспортного контролю та організації охорони державного кордону зі зброєю в руках. Частково це є правильним тлумаченням, навіть більшість просвітницьких матеріалів про прикордонну службу так їх і представляють - «на передньому плані» зброя. Проте варто наголосити на тому, що у змісті професійної діяльності офіцерів-прикордонників вагома частка професійних обов'язків потребують фундаментальної інтелектуальної підготовки. Зважаючи на це, в НАДПСУ для майбутніх фахівців створено такі спеціальності, як «Безпека державного кордону», «Філологія», «Автомобільний транспорт», «Телекомунікація», «Правоохоронна діяльність», «Психологія». Керівництво АДПСУ враховувало той факт, що у сучасних збройних та правоохоронних формуваннях з-поміж численної кількості посад $є$ посада штатного офіцера-психолога.

Діяльність офіцера-психолога в прикордонному колективі передбачає виконання прикладних та дослідницьких завдань у роботі з різними формами психічного стану військовослужбовців (солдатів та офіцерів) у мирний та воєнний час, надання психологічної підтримки та допомоги персоналу прикордонної служби та членам їхніх сімей.

Вище було наведено характеристику діяльності офіцера-психолога у прикордонному відомстві. Проте на особливу увагу заслуговують так звані надпрофесійні навички в офіцерів-прикордонників, що передбачають також здійснення психологічної допомоги, підтримки підпорядкованому персоналу та членам їхніх сімей. Річ у тому, що офіцери-прикордонники $є$ представниками професійної управлінської ланки відомства, а сучасний управлінський процес $\epsilon$ надзвичайно багатогранним та поліфункціональним. У межах цього управлінського процесу керівник прикордонного підрозділу повинен забезпечити його ефективне функціонування. Ефективність діяльності органів охорони державного кордону залежить від професійної діяльності ії персоналу. Зважаючи на це, офіцер-прикордонник повинен вміти оцінювати психологічний стан підпорядкованого персоналу.

Враховуючи вищенаведене, перед науковопедагогічним складом НАДПСУ постало декілька проблемних питань:

- які психологічні навчальні дисципліни включити у навчальні плани спеціальностей «Безпека державного кордону», «Філологія», «Автомобільний транспорт», «Телекомунікація», «Правоохоронна діяльність»;

- якою повинна бути кількість аудиторних годин на ознайомлення із цими навчальними дисциплінами;

- що повинен передбачати зміст освітньо-професійної програми, зокрема професійні, військові, загальні компетентності.

Науково-педагогічні працівники кафедри психології, педагогіки та соціально-економічних дисциплін НАДПСУ запропонували для згаданих вище непсихологічних спеціальностей таку навчальну дисципліну, як «Морально-психологічне забезпечення».

Специфіка викладання навчальної дисципліни «Морально-психологічне забезпечення» полягає в тому, що необхідно сформувати у майбутніх офіцерів-прикордонників культуру застосування психологічних знань, оволодіння ними як умову особистісного розвитку. Це вимагає особливого підходу щодо організації освітнього процесу в НАДПСУ, враховуючи зміст професійної діяльності майбутніх офіцерів-прикордонників. На наш погляд, побудова процесу вивчення навчальної дисципліни «Морально-психологічне забезпечення» повинна здійснюватися на засадах раціонального поєднання традиційного освітнього підходу та інноваційного; педагогіки співробітництва, що ідеально враховує індивідуалізацію навчання, відображає рефлексивний підхід, формує корпоративну культуру.

Перед науково-педагогічними працівниками сформульоване складне освітньо-наукове завдання: сформувати в майбутніх офіцерів-прикордонників вміння фокусуватися на психологічних завданнях та проблемах прикордонного 
колективу; сформувати високу швидкість реакції, уважність до деталей.

Загальноприйнятим $\epsilon$ поділ усіх психологів на три категорії: дослідницьку, практикуючу, освітню. Офіцери-прикордонники належать до практикуючих психологів, оскільки будуть використовувати отримані знання та вміння у межах певної спеціалізації. Їм необхідно дати знання про оперативно-службову та побутову сфери життя, про поведінку військовослужбовця у стресовій ситуації, вміння проводити соціально-психологічні бесіди та інтерв'ю, психологічний аналіз персоналу прикордонного підрозділу тощо.

Необхідно згадати про ще одну важливу особливість професійної діяльності офіцерів-прикордонників: високу змінність об'єктів діяльності. В офіцерів ДПСУ надзвичайно високий темп несення служби, часто виникає дефіцит часу, тому слід також сформувати в них уміння регулювати власний емоційний стан.

Дидактичні особливості викладання навчальної дисципліни «Морально-психологічне забезпечення» У НАДПСУ:

- доступне викладання (психологія використовує досить складну термінологію, а для майбутніх офіцерів-прикордонників психологічну освіту можна вважати початковою);

- відсутність систематичної психологічної підготовки майбутніх офіцерів-прикордонників вимагає від науково-педагогічних працівників здійснювати ретельну побудову тематичного плану (послідовну, логічну, раціональну) та добір педагогічних технологій, методик, методів, прийомів та засобів;

- формування основ критичного аналізу наукових положень;

- визначення рівня знайомства курсантів-прикордонників із досягненнями поп-психології (популярної психології, що формує хибні явлення про наукову психологію) і спрямування зусиль на заміщення хибних знань та умінь на професійні;

- виділення вагомої частки аудиторних годин на практичну підготовку (оволодіння навичками проведення психологічних досліджень у прикордонному колективі та обробки їх результатів);

- дотримання принципу міждисциплінарності (зв'язку навчальної дисципліни з гуманітарними, природничими та військово-професійними дисциплінами);

- забезпечення чуттєвого наповнення змісту психологічної підготовки (здатності до міркувань про психіку інших людей);

- дотримання принципу цінності наукових професійних умінь порівняно зі знаннями.

В освітньому процесі НАДПСУ під час викладання навчальної дисципліни «Морально-психологічне забезпечення» увагу приділено такому виду навчальних занять, як практичні. Саме на основі зміщення акценту з лекційних занять на практичні науково-педагогічні працівники досягають мети психологічної підготовки майбутніх офіцерів-прикордонників. Такий підхід реалізують із метою уникнення розриву між вітчизняною та західною підготовкою фахівців у секторі оборони та безпеки, а також між теорією та практикою. У західній освітній системі нині переважають практичні методи та форми навчання, як-то: тренінги, наставництво, коучинг, імітаційне навчання, рольові ігри, інтелект-карти та кейс-технології. Усі ці педагогічні інструменти дають змогу забезпечити високий рівень психологічної підготовки майбутніх офіцерів-прикордонників.

Висновки. Таким чином, визначені за результатами аналізу дидактичні особливості викладання психологічних навчальних дисциплін майбутнім офіцерам-прикордонникам непсихологічної спеціалізації доводять їх специфічність та дають змогу зробити висновок про наявність високої потреби у сформованості в офіцерських кадрів прикордонного відомства психологічних знань, умінь та навичок. Результати проведеної дослідної роботи можуть слугувати джерелом цінної інформації для керівників АДПСУ та для визначення шляхів удосконалення змісту професійної підготовки майбутніх офіцерів-прикордонників.

Навчально-методична база НАДПСУ має значний потенціал та потужності щодо забезпечення прикордонних підрозділів фахівцями оптимального рівня. Перспективними напрямами подальших наукових розвідок можуть бути питання щодо впровадження передового зарубіжного досвіду у підготовку вищезазначених фахівців сектору оборони та безпеки; пошуку педагогічних резервів для модернізації освітнього процесу у ВВНЗ.

\section{ЛIТЕРАТУРА}

1. Атанов Г.А. Возрождение дидактики - залог развития высшей школы. Донецьк, 2003. 175 с.

2. Бондарчук Е.И., Бондарчук Л.И. Основы психологии и педагогики: Курс лекцій. Киев : МАУП, 2001. $224 \mathrm{c}$.

3. Боровик Л.В. Місце психологічної компетентності офіцера-прикордонника у структурі його професіоналізму. Сучасна наука в мережі інтернет : матеріали шостої всеукраїнської наук.-практ. інтернет-конф. URL : http://intkonf.org/kand-psih-n-borovik-lv

4. Войцехівський О.Л. Підготовка майбутніх офіцерів-прикордонників до професійної діяльності в пунктах пропуску через державний кордон : дис. ... канд. пед. наук : 13.00 .04 «Теорія і методика професійної освіти». Хмельницький, 2012. 252 с. 
5. Івашкова Т.О. Формування культури самоосвіти майбутніх офіцерів правоохоронних органів у вищих навчальних закладах : автореф. дис. ... канд. пед. наук : спец. 13.00.04. Хмельницький, 2008. $20 \mathrm{c}$.

6. Матюх С.А. Вплив глобалізаційних процесів на формування освітніх послуг вищих навчальних закладів. Вісник Хмельницького наиіонального університету. 2014. № 3. Том 2. С. 259-263.

7. Подоляк Л.Г., Юрченко В.І. Психологія вищої школи : навчальний посібник для магістрантів і аспірантів. К. : ТОВ « Філ-студія», 2006. С. 195-209.

8. Пометун О.І. Дискусія українських педагогів навколо питань запровадження компетентнісного підходу в українській освіті. Компетентнісний підхід у сучасній освіті: світовий досвід та украӥнські перспективи: Бібліотека освітньої політики; під заг. ред. О.В. Овчарук. К. : «К.І.С.», 2004. 112 с.

9. Семиченко В.А. Методичні проблеми викладання психології у вищій школі [Електронний ресурс]. URL: //library.uipa.kharkov.ua/

10. Мороз Н.В. Формування соціокультурної компетенції як складової професійної підготовки курсантів вищих військових навчальних закладів : автореф. дис. ... канд. пед. наук : 13.00.04. Хмельницький, 2007. 20 с.

11. Торічний О. Потенціал інтерактивних технологій у формуванні фахової компетентності майбутніх офіцерів-прикордонників. Вісник Національної академії Державної прикордонної служби України. Серія: Педагогіка. 2016. Вип. 2. URL: http://nbuv.gov.ua/UJRN/Vnadped_2016_2_9

\section{REFERENCES}

1. Atanov G.A. (2003). Vozrozhdenye dydaktyky - zaloh razvytyya vysshey shkoly [Revival of didactics the key to the development of higher education]. Donetsk. $175 \mathrm{p}$.

2. Bondarchuk E.I., Bondarchuk L.I.(2001). Osnovy psykholohyy y pedahohyky : kurs lektsiy [Fundamentals of psychology and pedagogy : Lectures]. Kiev : MAUP. 224 p.

3. Borovik L.V. (2018). Mistse psykholohichnoyi kompetentnosti ofitsera-prykordonnyka u strukturi yoho profesionalizmu. Suchasna nauka $\mathrm{v}$ merezhi internet [The place of psychological competence of a border guard officer in the structure of his professionalism]. Modern science on the Internet: materials of the sixth all-Ukrainian scientific practice. internet conference. URL: http://intkonf.org/kand-psih-n-borovik-lv

4. Wojciechowski O.L. (2012). Pidhotovka maybutnikh ofitseriv-prykordonnykiv do profesiynoyi diyalnosti $\mathrm{v}$ punktakh propusku cherez derzhavnyy kordon [Preparation of future border guards for professional activities at checkpoints across the state border]: dis. ... cand. ped. Sciences: 13.00.04 "Theory and methods of vocational education". Khmelnytsky. 252 p.

5. Ivashkova T.O. (2008). Formuvannya kultury samoosvity maybutnikh ofitseriv pravookhoronnykh orhaniv $\mathrm{u}$ vyshchykh navchalnykh zakladakh [Formation of the culture of self-education of future law enforcement officers in higher educational institutions]: author's ref. dis. for science. degree of Cand. ped. Science: special. 13.00.04. Khmelnytsky. 20 p.

6. Matyukh S.A. (2014). Vplyv hlobalizatsiynykh protsesiv na formuvannya osvitnikh posluh vyshchykh navchalnykh zakladiv [Influence of globalization processes on the formation of educational services of higher educational institutions]. Bulletin of Khmelnytsky National University. № 3. Volume 2. Pp. 259-263.

7. Podoliak L.G., Yurchenko V.I. (2006). Psykholohiya vyshchoyi shkoly : navchalnyy posibnyk dlya mahistrantiv i aspirantiv [Psychology of higher education: A textbook for undergraduates and graduate students]. K. : Phil-Studio LLC. P. 195-209.

8. Pometun O.I. (2004). Dyskusiya ukrayinskykh pedahohiv navkolo pytan zaprovadzhennya kompetentnisnoho pidkhodu v ukrayinskiy osviti [Discussion of Ukrainian teachers around the introduction of a competency-based approach in Ukrainian education]. Competence approach in modern education: world experience and Ukrainian perspectives: Library of educational policy; under the general ed. OV Ovcharuk. K. : "KIS". 112 p.

9. Semichenko V.A. (2014). Metodychni problemy vykladannya psykholohiyi u vyshchiy shkoli [Methodical problems of teaching psychology in high school] [Electronic resource]. URL: http://library.uipa.kharkov.ua/

10. Moroz N.V. (2007). Formuvannya sotsiokulturnoyi kompetentsiyi yak skladovoyi profesiynoyi pidhotovky kursantiv vyshchykh viyskovykh navchalnykh zakladiv [Formation of socio-cultural competence as a component of professional training of cadets of higher military educational institutions] : author's ref. dis. ... Cand. ped. Science : 13.00.04. Khmelnytsky. 20 p.

11. Torichny O. (2016). Potentsial interaktyvnykh tekhnolohiy u formuvanni fakhovoyi kompetentnosti maybutnikh ofitseriv-prykordonnykiv. [The potential of interactive technologies in the formation of professional competence of future border guards]. Bulletin of the National Academy of the State Border Guard Service of Ukraine. Series: Pedagogy. Vip. 2. URL: http://nbuv.gov.ua/UJRN/Vnadped_2016_2_9. 